\title{
Medieval Origins: A Review Essay on Campbell's The Great Transition
}

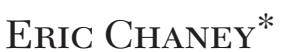

Bruce M. S. Campbell's The Great Transition: Climate, Disease and Society in the Late-Medieval World is a significant contribution to the growing literature that traces the roots of Europe's economic rise to the climatic and population shocks of the late medieval period. This review essay discusses the empirical, historical, and theoretical support for Campbell's view while highlighting that it struggles to explain why these positive effects were limited to Europe. It then hypothesizes that Europe's differential response to this shock reflected prior institutional advantages and provides some preliminary empirical evidence in support of this hypothesis. The essay concludes by examining Campbell's claim that these shocks contributed to Atlantic Europe's rise prior to the colonial period. (JEL I15, J11, J13, N13, N33, Q54)

\section{Introduction}

$\mathrm{T}$ he origins of the Western World's economic rise continue to both intrigue and divide scholars. Whereas some highlight the central importance of events in the decades running up to the Industrial Revolution, others view the economic rise of the West as the culmination of historical processes with roots reaching back to the medieval period. In this debate, studies have often looked to pinpoint the exact period in which Europe overtook China (or the Islamic world) in an attempt to adjudicate between competing hypotheses. The Great Transition: Climate, Disease and Society in the Late-Medieval World by Bruce

\footnotetext{
* Oxford University. I thank Daniel Lowery for outstanding research assistance. I am responsible for all remaining errors

${ }^{\dagger}$ Go to https://doi.org/10.1257/jel.20161417 to visit the article page and view author disclosure statement(s).
}

M.S. Campbell is a significant contribution to this literature, arguing that Europe drew even with and then overtook China roughly in the middle of the "Great Transition" (henceforth, Transition), which spanned approximately 1270 to $1470 \mathrm{CE}$. In this sense, his book argues that the Transition laid the groundwork for the Great Divergence.

Although the book contains a wealth of analysis of climatic, population, and economic data, as I see it, its core is composed of four main arguments:

1. A period of benign climatic conditions known as the Medieval Climate Anomaly interacted with Europe's institutional framework to generate rapid development in Western Europe starting in approximately 1100. This economic growth led to increasing urbanization and population density 
until growth began to slow in the second half of the thirteenth century.

2. By the end of the thirteenth century, a growing "burden of poverty" had made the "kinds of structural change that might have generated economic growth" less likely (Campbell 2016, p. 257). At this point of economic stagnation, climate change increased the incidence of extreme weather events and facilitated the spread of the Black Death across Eurasia."]

3. Although wages rose in response to the sharp decrease in population following the Black Death, adverse climatic and political conditions ensured that population did not rapidly recover to preplague levels. This state of affairs lasted through the middle of the fifteenth century leading to a "shift in socio-ecological regime” (Campbell 2016, p. 332).

4. A shift to a more benign climate in the later fifteenth century marks the end of this period of transition and, when combined with the changes that occurred over previous centuries of crises, helped propel Europe to a new era of economic vigor.

Campbell's detailed narrative roots the Transition in a combination of human and environmental occurrences-increased warfare and decreased trade mixed with climate change and plague-that ushered in a new "socio-ecologial regime" that transferred European economic leadership away from the Mediterranean and toward the Low Countries and England.

1 The Black Death of 1350 was a devastating pandemic that killed between one-third and one-half of the European population (Voigtlander and Voth 2013a, p. 165).
The book is innovative, among other reasons, because it views the advent of the Black Death-which was arguably the Transition's central event-as the downstream outcome of climatic changes during this period (Campbell 2016, p. 319). This seems plausible and has the benefit of neatly explaining why European populations did not immediately bounce back following the Black Death.

At some level, however, the book ultimately seeks to advance our understanding of how these climatic shocks facilitated the economic rise of the Western world. In this aim, the book is less successful and feels incomplete. Perhaps this is because the author claims that this period "initiated irreversible regime change" (Campbell 2016, p. 399) and yet is reluctant to concisely spell out the relevant changes, as well as the mechanisms through which the climatic and population shocks of the late medieval period led Europe in a different direction. In other words, Campbell elegantly and convincingly demonstrates the centrality and complexity of the Transition, and demonstrates the shift of economic leadership toward Europe during this period, but he falls short of pinpointing why the Transition ultimately ended in the Great Divergence.

In this essay, I consequently focus on better understanding the Transition's place in Europe's long-run development path. In the next section, I discuss existing views of the Black Death's role in European economic history and situate Campbell's contribution in this literature. I note that, although this literature provides important insights, it struggles to explain why the Black Death did not have similar effects in non-European areas. Section 3 argues that Europe's unique institutional framework on the eve of the Black Death may explain this differential response, although it also notes that these institutional differences make it difficult to identify the independent effect of the Transition. The fourth section uses a proxy for economic 
development over the long run to evaluate Campbell's claim that the Transition altered Europe's growth path. These results provide support for the Transition's importance, showing that differential European growth over the medieval period largely came from what would become the "Atlantic traders" defined in Acemoglu, Johnson, and Robinson (2005). The fifth section concludes with a brief discussion of possible explanations for this differential growth and notes the need for more research on what increasingly appears to be a transformative phase of European economic history.

\section{The Transition in European Economic History}

Although the Black Death is generally viewed as a watershed event in European economic history, the exact nature of this shock remains a topic of disagreement. Broadly speaking, existing scholarship can be divided into what I will call the deterministic and non-deterministic camps.

North and Thomas (1970) provide a classic take on the deterministic view, arguing that the Black Death was a manifestation of a larger Malthusian crisis. In particular, they believe that population growth led to decreases in the marginal product of labor by the late thirteenth century. ${ }^{2}$ This fall in real wages rendered the population more susceptible to both famine and disease, which explains, in turn, the fourteenth-century spread of the Black Death. In other words, the Black Death is viewed as the endogenous product of population growth in the Malthusian era.

Campbell (2016, p. 393) adopts the non-deterministic view that assigns the Black

\footnotetext{
${ }^{2}$ This relationship between population and labor's marginal production follows immediately from the fact that land was both a key and fixed factor of production during this period.
}

Death a more fundamental role in Europe's growth path. He suggests that climatic changes facilitated the spread of the Black Death and thus played a central role in the Transition acting as a transformative tipping point, rather than a mere consequence of other factors (e.g., Campbell 2016, p. 267). In his view, without the Transition, Europe would have remained mired in a labor-abundant, low-wage equilibrium (Campbell 2016, p 257).

Campbell's skepticism of the deterministic view finds some support in the experiences of non-European populations in the centuries prior to the Transition. For example, the deterministic view implies that population dynamics should have been similar in Europe and the Islamic world prior to the Black Death's onset. ${ }^{\beta}$ The historical record is not consistent with this prediction, however, in the sense that Europe was rebounding over the previous centuries from very low levels of population density, whereas the Islamic world was not.

The experience of non-European societies during the Transition also raises questions for non-determinists such as Campbell who assign the Black Death a pivotal role in European economic history. Why, for example, did the Black Death not have similar growth-enhancing effects in both the Islamic world and Western Europe? The answer to this question, of course, depends on the exact mechanisms through which the Black Death affected Europe's socioeconomic equilibrium.

In a recent string of articles, Voigtlander and Voth (2013a, 2013b, and 2013c) outline a few channels through which the Black Death may have had enduring effects. Voigtlander

\footnotetext{
${ }^{3}$ This follows from the fact that both Europe and the Islamic world were equally hard hit by the Black Death (Dols 1977, p. 55). Thus, if the Black Death was the inevitable consequence of overpopulation, both regions should have been similarly overpopulated in the run up to this population shock.
} 
and Voth (2013a, p. 168) argue that the postBlack Death surge in agricultural surplus led to an increase in state revenues and increased warfare. This increase in warfare led to increased mortality that worked to both keep population densities low and incomes high. They also argue the Black Death encouraged urbanization (Voigtlander and Voth 2013c) and led to a decrease in fertility (Voigtlander and Voth 2013b).

These authors also argue that labor shortage and warfare may have encouraged innovation (Voigtlander and Voth 2013a, p. 181). This view is consistent with Herlihy (1977, p. 49), who argues that labor scarcity following the Black Death led to "impressive technological achievement," although recent theoretical work suggests that labor scarcity, in and of itself, is insufficient to induce technological innovation (Acemoglu 2010).

The most careful studies of the effects of the Black Death thus recognize that this shock must have interacted with something in Europe. Voigtlander and Voth (2013c) argue that Europe's unique response to the Black Death was rooted in the proliferation of states within Europe. They focus on comparisons with China, stressing that because China was politically unified, there was less scope for warfare. This explanation seems to work well for China and the hypothesis fits nicely within the literature arguing that political competition between European states-which often took the form of warfare-was central to European state formation (e.g., Tilly 1985).

This literature, however, largely overlooks the Islamic world, which was arguably more developed than China for much of the medieval period. Comparisons between Europe and the Islamic world cast doubt on the ability of intrastate military competition to explain Europe's abnormal response to the Black Death.

First of all, part of Europe belonged to the Islamic world during the Transition (e.g., the Kingdom of Granada) and other regions such as North Africa were in such close proximity and constant conflict with European powers that it seems most natural to view them as part of the European state system. ${ }^{7}$ Second, contrary to what is regularly asserted, there were many states in the Islamic world during this period. For example, during the fourteenth century, the relatively small fertile strip of land on the Mediterranean coast of North Africa alone was divided between the Marinids, Zayyanids, Hafsids, and Mamluks.

If the number of states and prevalence of warfare does not distinguish Europe from the Islamic world during this period, what does? The answer provided by authors such as Max Weber seems to point in the right direction. In his corpus of work, Weber stresses the importance of the emergence of impersonal institutions - or in his terminology, the greater rationality of European law-in explaining why Europe was different from the rest of the world. In his view, these institutions were ultimately a reflection, at least in part, of Europe's unique political equilibrium (Trubek 1972, p. 738).

While the relationship between Europe's institutions and the region's underlying political equilibrium remains a topic of ongoing research, recent scholarship provides significant evidence that both were unique prior to the Transition. From an institutional standpoint, scholars have often focused on legal institutions (e.g., Cantoni and Yuchtman 2014) as well as the importance of the emergence of self-governing corporations during this period (e.g., Greif 2006, p. 390).

\footnotetext{
${ }^{4}$ For an overview of the constant nature of conflict between Europe and North Africa from a slightly later era, see Chaney (2015).

${ }^{5}$ See the appendix to Blaydes and Chaney (2013) for a list of dynasties in the Islamic world in this period, which is close in number to those in Western Europe, and Stasavage (2016) for evidence that the incidence of warfare inside and outside of Europe was similar.
} 
Politically, the literature stresses the unique degree to which European sovereigns were constrained (Stasavage 2016).

This unique socioeconomic equilibrium is believed to be rooted in the chaotic centuries following the collapse of the Western Roman Empire (e.g., Stasavage 2016). Chaney (2012) draws on Blaydes and Chaney (2013) to argue that the rise of a landed aristocracy in Europe broke fundamentally with what came before. The emergence of a landed nobility led to a "separation of powers" between the king, the aristocracy, and the Church that made it more difficult for any of these groups to curtail freedoms. This framework suggests that the emergence of representative institutions, self-governing corporations, and impersonal institutions ultimately reflected a political equilibrium in which political power was abnormally fractured at the local level. For example, politically powerful groups could grant liberties to individuals, cities, and corporations in order to undercut rivals.

This analysis suggests that the fracturing of political power within states, and not the number of states, is what made pre-Transition Europe unique. This within-state model plausibly explains why European states responded differently to war than their Islamic counterparts. In the Islamic world, rulers faced fewer internal constraints and were infrequently forced to bargain with local elites. Thus, contrary to what occurred in Europe, war did not "make states" in the Islamic world. This could help explain how the uncertainty and chaos described by Campbell contributed to Europe's eventual divergence from other regions such as China and the Islamic world that experienced similar climatic and biological shocks, and yet reacted differently. In the following sections, I discuss in greater detail the extent to which preexisting political and institutional differences can explain the Transition's abnormal effects within Europe.

\section{Institutions and the Transition}

The idea that the Black Death interacted in important ways with the pre-Transition institutional framework goes back at least to Brenner (1985). He notes that although the Black Death struck both Western and Eastern Europe, these regions responded differently to the subsequent scarcity of labor. In Western Europe, labor scarcity increased the bargaining power of peasants, which led to the end of serfdom (Brenner 1985, p. 34). In Eastern Europe, however, this same population shock is thought to have led to an increase in labor coercion. ${ }^{6}$ Brenner (1985, p. 40) ultimately attributes the differential response to this shock to the greater strength of peasant organization at the village level in Western Europe prior to the Black Death.

Of course, this conclusion requires further investigation into why peasant organization in the West was more robust than in the East. Blum (1957, p. 809) suggests that the answer to this question may be found in the greater strength of the monarchy in Western Europe. The monarchy, in this view, worked to strengthen peasant communities in an effort to undermine the nobility. This author contrasts this state of affairs with that of Eastern Europe, where the monarchy was weaker and consequently the nobility faced fewer constraints than in the West. Although there is little agreement regarding the causes behind the greater strength of the monarchy in Western Europe, it may be related to the growth of trade and the concomitant increase in tax revenues flowing to the monarchy that began in Western Europe during the late eleventh century. The reasons why

\footnotetext{
${ }^{6}$ See Acemoglu and Wolitzky (2011) for a formal treatment of the relationship between labor coercion and labor scarcity and Chaney and Hornbeck (2016) for empirical evidence of the importance of pre-shock arrangements in determining how a society responds to population shocks.
} 
Eastern Europe did not follow a similar trajectory may be explained by the fact that this region was being colonized by the nobility during this period. This helps to explain both the political strength of the nobility, as well as the fact that cities were considerably weaker in Eastern Europe than in the West (e.g., Brenner 1985, p. 38).

Whatever the nature and origins of the institutional differences between Western and Eastern Europe, there is growing evidence that Western Europe enjoyed institutional advantages over China and the Islamic world even prior to the Transition. For example, Blaydes and Chaney (2013) provide empirical evidence of an increase in political stability in Western Europe in the run up to the Transition and argue that this increase reflected increased constraints on sovereigns across Europe. In figure 1, I reproduce the moving averages presented in that article, while also adding China. 7 This graph suggests that Europe enjoyed greater political stability well before the start of the Transition. As noted above, Blaydes and Chaney (2013) ultimately link this increase to the rise of a landed aristocracy in Western Europe.

This evidence raises difficulties for those who assign the Transition and its accompanying climatic and population shocks a central role in Europe's growth path. In particular, if Europe's pre-Transition institutional framework already gave it important advantages, it is harder to disentangle the independent role of the Transition from an empirical

\footnotetext{
7The China data are drawn from the China section of http://www.oxfordreference.com/ view/10.1093/acref/9780191780073.001.0001/ acref-9780191780073?rskey $=$ dUrUGc\&result $=1$. For the Islamic and European rulers, I use a one-hundred-year rear moving average, whereas for China I use a 400 year rear moving average primarily for expositional clarity given that there are many fewer rulers in China (a consequence of the smaller degree of political fragmentation in this region). The general conclusion that ruler durations are increasing in Europe and not in the other two regions over this period, however, is robust.
}

standpoint. In the ideal world, we would observe the growth path of a counterfactual Europe in the Transition's absence. Although this counterfactual is unobservable, there is some evidence that Europe's medieval institutional framework was the fundamental driver of its abnormal developmental path, which was perhaps facilitated, but not caused, by the Transition.

Campbell (2016, p. 36) attributes the economic growth in the pre-Transition era to developments such as the "resurgence of the Latin Church, birth of the "Western legal tradition," state formation, institution of self-regulating urban communes, guilds and commonfield communities." Although it is difficult to argue that these developments did not contribute to Europe's pre-Transition growth, it is also the case that many of these institutions bear a striking resemblance to those that continue to govern the Western world today (e.g., Greif 2006, p. 379). This observation has led Greif (2006, p. 398) to suggest that these institutions may "have cultivated the seeds of the Rise of the West."

The observation that Europe's rise is rooted in the pre-Transition period is consistent with the historical evidence. For example, European colonial expansion began in earnest in the late eleventh century and not with the New World discoveries, as is implied in many studies. For example, both the conquest of Islamic Sicily as well as that of Islamic Iberia gathered strength toward the end of the eleventh century. This colonial expansion was also manifested in the expansion of Germanic settlement to the east of the Elbe and in the Crusades (Phillips 1998, pp. 20, 50). In general, this expansion seems to have been qualitatively different from what had come before and is believed to reflect these "fundamental developments within western Europe" (Phillips 1998, p. 16).

This evidence raises the possibility that the Transition was ultimately irrelevant for 


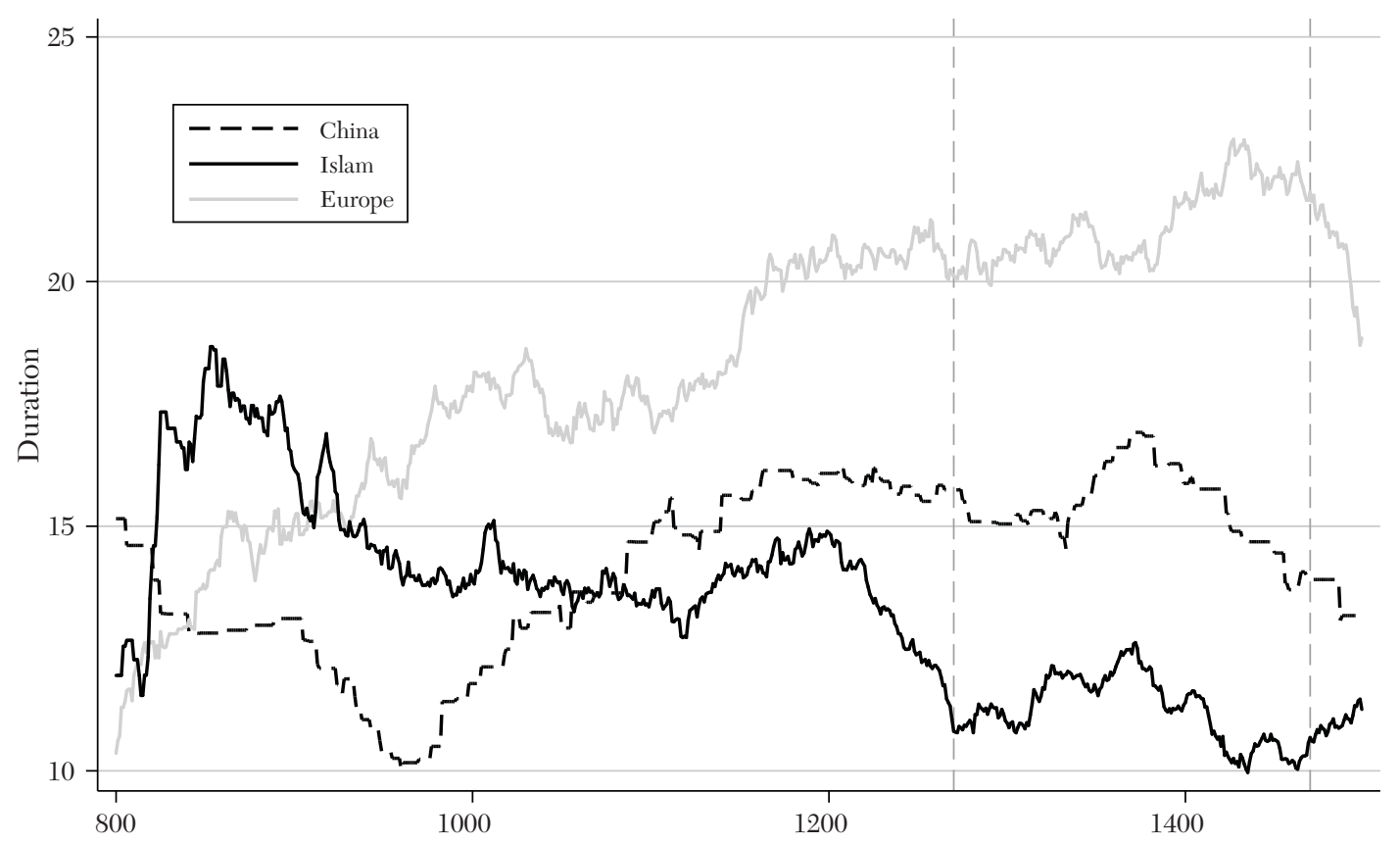

Start Year of Reign

Figure 1. Political Divergence Before the Transition

Notes: Moving average of ruler durations in Europe, the Islamic world, and China. The two vertical lines mark the years 1270 and 1470, which are the approximate bounds of the Transition.

Western Europe's economic rise, in the sense that the pivotal changes to Europe's institutional framework occurred prior to the Transition. In other words, while the Transition might have slowed down or sped up the relevant processes, these would have happened in the Transition's absence. Although it is impossible to prove this claim given the current state of empirical and historical work on this period, in the following section I provide some empirical evidence that supports the centrality of pre-Transition institutions as the ultimate driver of the Great Divergence.

\section{What Did the Transition Do?}

One of Campbell's central claims is that Europe grew faster than China during the Transition (Campbell 2016, p. 400). Empirically, however, data constraints have limited the ability to test such hypotheses. A few years ago, Buringh and van Zanden (2009) argued that book production may be the best available proxy for economic development during this early period. Although these authors provide much evidence in support of this claim, perhaps the link between urbanization and book production is the most 


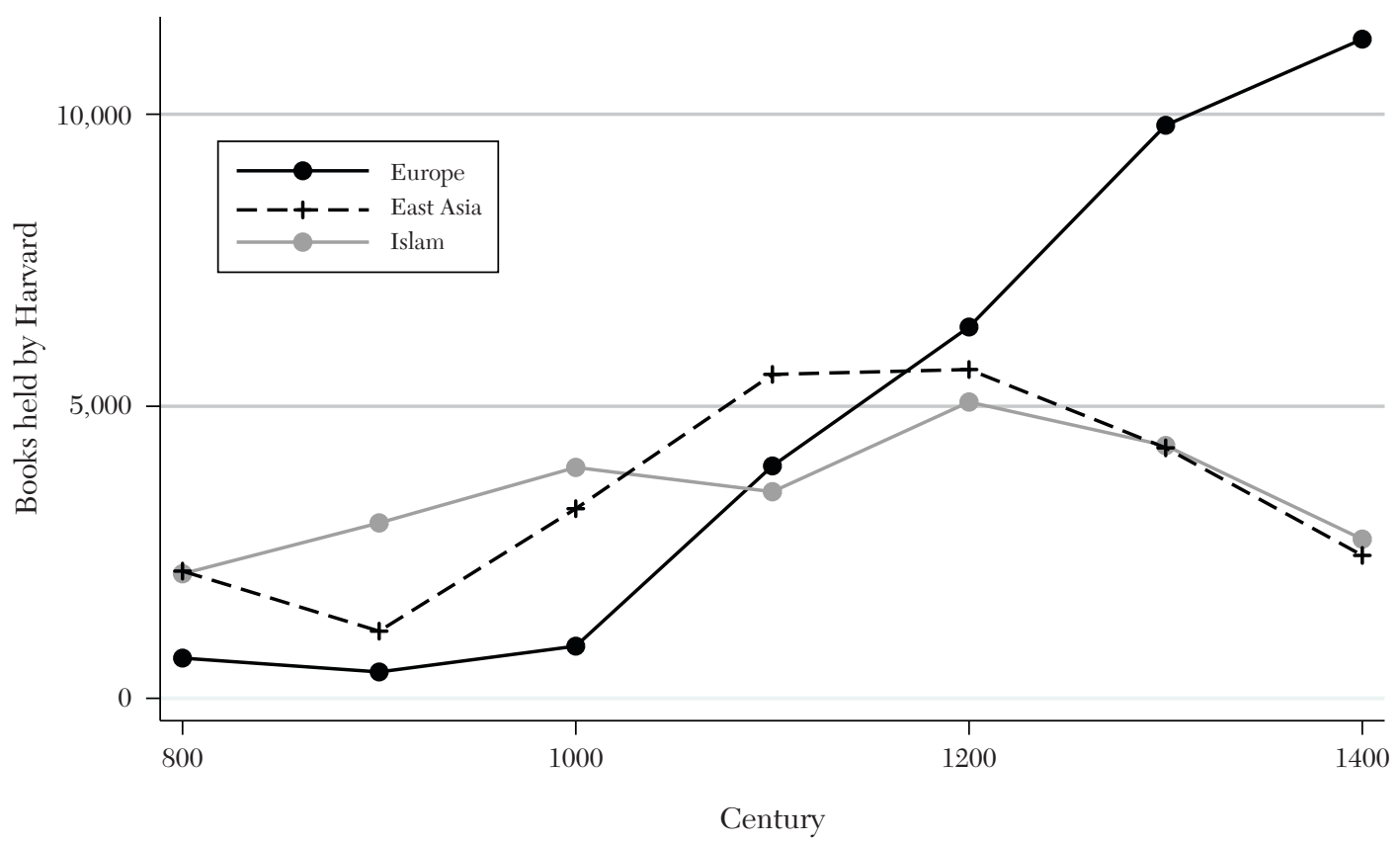

Figure 2. Book Holdings of Harvard Libraries

Note: Number of books held by Harvard libraries by century of death and geographical region.

compelling, since urbanization is a generally accepted proxy for economic development. In light of this evidence, throughout the remainder of this essay I use the total number of books held by Harvard University libraries that were written by authors from a given region that died in year $t$ as a proxy for the level of development in a region and year $t$.

In figure 2, I plot the total number of books by century for authors with European, Islamic, or East Asian sounding names. . $^{\text {In }}$ some ways, these trends are consistent with Campbell's view of the relative development of these regions during the medieval

${ }^{8}$ To be precise, East Asian sounding names are all names that are not European or Islamic sounding. The overwhelming majority of these are East Asian sounding. period. It should be stressed, however, that I view these results as exploratory. 9 Thus, figure 2 suggests that Europe did grow faster than both East Asia and the Islamic world during the Transition, as Campbell claims. However, figure 2 also shows that Europe was growing faster than these regions prior to the Transition.

To better understand Europe's growth during this period, I limit the sample to European authors who died in the interval $[800,1800)$ and analyze the data at the year

\footnotetext{
${ }^{9}$ While Harvard's collections are probably not a random sample of all intellectual production ever produced, the time-varying selection necessary to explain away the general trends presented below seems unlikely. Harvard's library is the largest university library in the world and I describe this collection and the data in greater detail in Chaney (2016).
} 
level. In particular, I search for trend breaks in the specification:

$$
\begin{aligned}
\ln \left(\text { book }_{t}\right) & =\gamma_{j}+\delta_{j} t+u_{t} \\
t & =T_{j-1}+1, \ldots, T_{j}
\end{aligned}
$$

where I follow the notation in Bai and Perron (2003) and use $m$ to denote the number of breaks $(m+1$ regimes), for $j=1, \ldots, m+1$. $\ln (\text { books })_{t}$ is the logarithm of one plus the total number of books written by European authors who died in year $t$ and $u_{t}$ is the disturbance term. The break points $\left(T_{1}, \ldots, T_{m}\right.$; $\left.T_{0}=0, T_{m+1}=T\right)$ are treated as unknown. This specification selects three breaks (four regimes), with point estimates of 1096, 1384, and 1526. ${ }^{10}$ The fitted values obtained from this specification as well as smoothed values (obtained with a lowess smoother and a bandwidth of 0.05) of the number of books written are provided in figure $3 . .^{11}$

The first regime, which runs from the start of the sample until 1096, displays little growth. After 1096, there is an increase in the growth rate. Between 1384 and 1526 there was another increase in the growth rate until 1526, after which the growth rate slows back to roughly that of the pre-1384 regime. Thus, these data assign the Transition to the interval between 1384 and 1526 in the sense that, in this period, there was an increase in this proxy for economic development. The dashed line in figure 3 provides fitted values obtained extrapolating the 1096-1384 growth rate forward to the end of the sample. This exercise suggests that in 1799, European book production would have been

\footnotetext{
${ }^{10}$ The 95 percent confidence intervals for these breaks respectively span the intervals 1093 to 1124,1341 to 1386 , and 1519 to 1531 .

${ }^{11}$ From a technical standpoint, I set $m=8$ and use 10 percent trimming. I apply $\mathrm{AR}(1)$ prewhitening and allow for the variance of the residuals to be different across segments. I use the Bayesian information criterion procedure to select the number of breaks.
}

$92 \log$ points or 151 percent lower had the Transition not happened. This simple calculation provides empirical evidence that the Transition played a positive role in Europe's overall growth trajectory, but it also casts doubt on the claim that the Transition was the fundamental cause of Europe's abnormal growth trajectory.

Although these results are consistent with the claim that the "Transition mattered," they do not shed light on the mechanisms through which the Transition had growth-enhancing effects. For example, the start of European growth in 1096 is very close to the host of legal institutional changes discussed in Berman (1983). Thus, the results are also consistent with Greif's conjecture that this medieval institutional complex was the fundamental cause of Europe's subsequent abnormal growth path. In other words, the results are consistent with the claim that the Transition sped up whatever processes were in motion prior to this event.

Epstein (2000, pp. 55, 69) adopts this view, arguing that the Transition accelerated the process of political centralization that had begun centuries earlier with the emergence of feudal institutions. In particular, he suggests that the Black Death worked to strengthen the political power of the monarchy, which in turn undermined the jurisdictional powers of the nobility, thus making markets more competitive and stimulating commerce (Epstein 2000, p. 55). While the exact process through which this occurred remains a bit of a black box, Epstein notes that the collapse in public and private interest rates during the Transition provides significant evidence of institutional improvements after the Black Death (Epstein 2000, pp. 60,61 ).

To more closely examine the geography of European growth during the medieval period, I geo-reference all European authors who died on the interval $[800,1500)$ and mimic the analysis in Acemoglu, Johnson, 


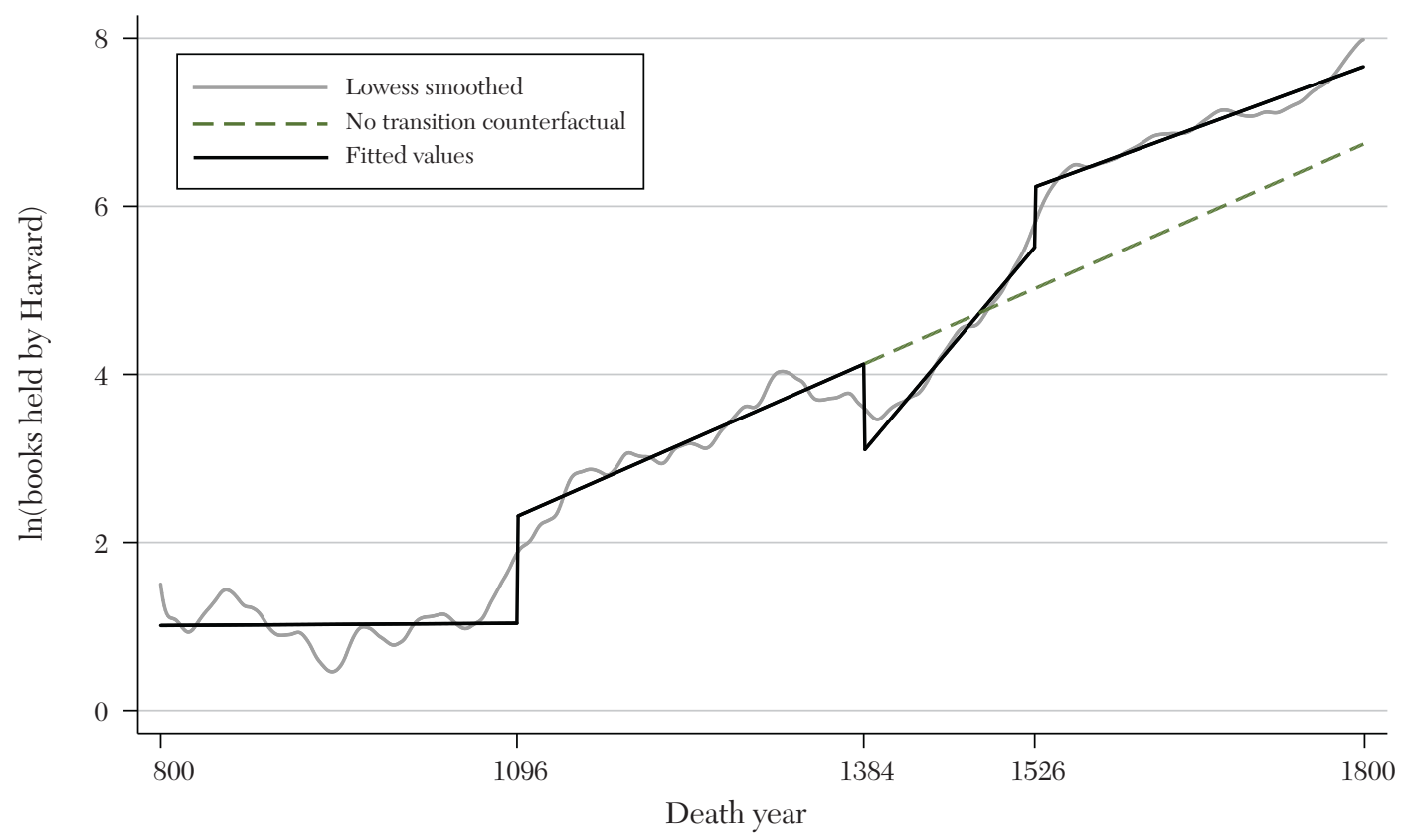

Figure 3. The Four Growth Regimes in Europe's Run-up to the Industrial Revolution

and Robinson (2005) for the medieval period by running the regression:

$$
\begin{aligned}
& \ln \left(\text { books }_{j t}\right)=d_{t}+\delta_{j} \\
& +\sum_{t \geq 1100}\left[\gamma_{t} \cdot \text { Europe }_{j} \cdot d_{t}+\alpha_{t} \cdot W E_{j} \cdot d_{t}\right. \\
& \left.\quad+\beta_{t} \cdot \text { PAT }_{j} \cdot d_{t}\right]+\epsilon_{j t}
\end{aligned}
$$

where $\ln \left(\right.$ books $\left._{j t}\right)$ is the logarithm of one plus the number of books written by authors born in modern-day country $j$ and century $t$, Europe $_{j}$ is a dummy indicating whether a country is in Europe, $W E_{j}$ whether a country is in Western Europe, $d_{t}$ denote century dummies and $\delta_{j}$ country dummies..$^{12}$ Finally,

12I define Europe according the data in the shapefile provided here: https:/www.arcgis.com/home/item. html?id=3864c63872d84aec91933618e3815dd2. I only
$P A T_{j}$ is an indicator for whether a country would become an Atlantic trader after the discovery of the Americas (i.e., it is equal to one for Britain, France, the Netherlands, Portugal, and Spain). Here the omitted regions are East Asia and the Islamic world.

In the first column of table 1. I present results from equation (2) omitting both

include countries that have at least one book written by an author born in that country in the interval $[800,1500)$. In addition, I assign books written by authors born in modern-day Monaco to France. The thirty-seven countries comprising Europe include (western Europe in bold) Albania, Austria, Belarus, Belgium, Bulgaria, Croatia, Czech Republic, Denmark, Estonia, Finland, France, Germany, Greece, Hungary, Iceland, Ireland, Italy, Liechtenstein, Lithuania, Luxembourg, Macedonia, Montenegro, the Netherlands, Norway, Poland, Portugal, Romania, Russia, Serbia, Slovakia, Slovenia, Spain, Sweden, Switzerland, Turkey, Ukraine, and the United Kingdom. 
TABLE 1

The Rise of Atlantic Europe: 800-1500 CE

\begin{tabular}{|c|c|c|c|c|c|}
\hline & $\begin{array}{l}\text { All } \\
(1)\end{array}$ & $\begin{array}{l}\text { All } \\
(2)\end{array}$ & $\begin{array}{l}\text { All } \\
(3)\end{array}$ & $\begin{array}{c}\text { Without } \\
\text { UK } \\
(4)\end{array}$ & $\begin{array}{c}\text { Only } \\
\text { Iberia } \\
(5)\end{array}$ \\
\hline $\begin{array}{l}p \text {-value for Europe } \\
\quad \times \text { year dummies, } 1100-1200\end{array}$ & {$[0.02]$} & {$[0.86]$} & {$[0.86]$} & {$[0.87]$} & {$[0.87]$} \\
\hline $\begin{array}{l}p \text {-value for Europe } \\
\quad \times \text { year dummies, } 1300-1400\end{array}$ & {$[0.00]$} & {$[0.00]$} & {$[0.00]$} & {$[0.00]$} & {$[0.00]$} \\
\hline $\mathrm{WE} \times 1100$ & & $\begin{array}{c}0.54 \\
(0.36)\end{array}$ & $\begin{array}{c}0.18 \\
(0.39)\end{array}$ & $\begin{array}{c}0.18 \\
(0.39)\end{array}$ & $\begin{array}{c}0.18 \\
(0.39)\end{array}$ \\
\hline $\mathrm{WE} \times 1200$ & & $\begin{array}{l}1.46 \\
(0.40)\end{array}$ & $\begin{array}{l}1.18 \\
(0.46)\end{array}$ & $\begin{array}{l}1.18 \\
(0.46)\end{array}$ & $\begin{array}{l}1.18 \\
(0.46)\end{array}$ \\
\hline $\mathrm{WE} \times 1300$ & & $\begin{array}{l}1.26 \\
(0.36)\end{array}$ & $\begin{array}{c}0.83 \\
(0.43)\end{array}$ & $\begin{array}{c}0.83 \\
(0.43)\end{array}$ & $\begin{array}{c}0.83 \\
(0.43)\end{array}$ \\
\hline $\mathrm{WE} \times 1400$ & & $\begin{array}{c}0.35 \\
(0.43)\end{array}$ & $\begin{array}{l}-0.31 \\
(0.45)\end{array}$ & $\begin{array}{l}-0.31 \\
(0.45)\end{array}$ & $\begin{array}{c}-0.31 \\
(0.45)\end{array}$ \\
\hline Potential for Atlantic trade $\times 1100$ & & & $\begin{array}{l}1.29 \\
(0.55)\end{array}$ & $\begin{array}{c}1.21 \\
(0.63)\end{array}$ & $\begin{array}{c}1.02 \\
(0.95)\end{array}$ \\
\hline Potential for Atlantic trade $\times 1200$ & & & $\begin{array}{c}0.98 \\
(0.60)\end{array}$ & $\begin{array}{c}1.04 \\
(0.68)\end{array}$ & $\begin{array}{l}2.07 \\
(0.60)\end{array}$ \\
\hline Potential for Atlantic trade $\times 1300$ & & & $\begin{array}{c}1.53 \\
(0.52)\end{array}$ & $\begin{array}{c}1.58 \\
(0.56)\end{array}$ & $\begin{array}{c}2.13 \\
(0.73)\end{array}$ \\
\hline Potential for Atlantic trade $\times 1400$ & & & $\begin{array}{c}2.35 \\
(0.55)\end{array}$ & $\begin{array}{c}2.39 \\
(0.62)\end{array}$ & $\begin{array}{c}3.19 \\
(0.65)\end{array}$ \\
\hline$R^{2}$ & 0.87 & 0.88 & 0.89 & 0.89 & 0.89 \\
\hline Observations & 273 & 273 & 273 & 266 & 252 \\
\hline
\end{tabular}

the $W E_{j}$ and $P A T_{j}$ interactions. The first two rows of this column present the $p$-values corresponding to the null hypothesis that the coefficients on the 1100-1200 and 1300-1400 Europe dummies are jointly equal to zero. These statistically confirm the graphical evidence presented above that Europe was growing faster than the Islamic world and China over this period.

In the second column of table 1 , I present results adding the $W E_{j}$ interactions. The coefficients on these interactions provide the differential growth of Western European regions for a given century when compared to Eastern European ones. When these interactions are included, I cannot reject the null that Eastern Europe grew at the same rate as China and the Islamic world prior to the Transition, although there is evidence that Eastern Europe grew faster during the Transition. Moreover, although Western Europe grew faster than Eastern Europe prior to the Transition, this was reversed during the Transition-by the fifteenth century, book production in Western Europe had only grown by 35 log points more than Eastern Europe. 
In the third column of table 1, I present results including all the interactions from equation (2). These results show that the Atlantic traders grew significantly faster than the rest of Western Europe prior to the discovery of the Americas. For instance, the coefficient on the 1400 Atlantic traders interaction implies that book production in the Atlantic traders grew by $235 \log$ points more than in the rest of Western Europe over the interval 800-1000, 1400. In column 4, I show that this result is not driven by the United Kingdom (i.e., I omit the United Kingdom from the sample). In column 5 , I show that the results are qualitatively similar when I limit the Atlantic traders to Portugal and Spain (i.e., when I drop the United Kingdom, France, and the Netherlands), which are hypothesized in some studies to have exhibited different political characteristics from the other Atlantic traders during the medieval period (e.g., Acemoglu, Johnson, and Robinson 2005). These results weigh against Acemoglu, Johnson, and Robinson (2005), who argue that the Atlantic regions were not growing faster than the rest of Europe in the run-up to the discovery of the Americas and are more consistent with recent research (e.g., Pamuk 2007) arguing that northwestern Europe grew faster than the rest of the continent in the centuries prior to the discovery of the Americas.

\section{Atlantic Europe's Medieval Rise?}

Campbell argues that structural changes during the Transition led to the rise of the Atlantic traders of northwestern Europe. While the available evidence is consistent with this claim, it also shows that Iberia was growing faster than the rest of Western Europe during this period. ${ }^{13}$

\footnotetext{
${ }^{13}$ In many ways this result is not surprising, given historical evidence of the technological and military vigor of what are today Spain and Portugal during this period.
}

What explains this medieval rise of Atlantic Europe? Some evidence points to the abnormal levels of freedom that many of the Atlantic traders enjoyed prior to the Transition. For example, contrary to the traditional view espoused in Acemoglu, Johnson, and Robinson (2005), there is evidence that local government in much of the Iberian peninsula during this period was "essentially democratic" (De Hinojosa 1903, p. 65). Such evidence has led scholars to claim that this region was perhaps "the freest society in Europe" (Thompson 1994, p. 142). Similarly, van Bavel and van Zanden (2004) suggest that the Netherland's dynamic growth in the late medieval period may have been a product of the relative weakness of the nobility in this region. In other words, while some regional differences in political organization existed, it seems plausible that the Atlantic traders led the Great Divergence because of a shared experience of greater medieval freedoms. These freedoms, in turn, seem to be rooted in the centuries prior to the Transition.

Of course, it is impossible to convincingly evaluate such claims in this essay. Hopefully, future research will shed greater light on the extent to which the process of state formation in medieval Iberia shared similarities with those of northwestern Europe's Atlantic traders.

Was the Transition central to the rise of Atlantic Europe and that of Europe more generally? Although Campbell convincingly shows that the "Transition mattered," it is also increasingly clear that Europe possessed institutional advantages that predated this event. These institutional differences are central to understanding the Transition and the Great Divergence, suggesting that in the end, Europe's medieval institutional complex, not the Transition, was the fundamental cause of its eventual rise.

Clearly, however, our understanding of these medieval developments is incomplete. 
In this essay, I have suggested that the Transition may have accelerated the process of European state formation and institutional change. The existing literature, however, does not do much to unpack this black box. Despite these gaps in our understanding, however, it does seem increasingly clear that Campbell is correct in suggesting that the roots of the economic rise of the Western world preceded the discovery of the Americas. This is an important step forward in the large literature seeking to understand Europe's economic rise.

In recent years, much research has focused on describing how "bad institutions" arise and thwart economic development. Yet our understanding of how "good institutions" arise remains incomplete. To the extent that the pre-Transition era did contain "the seeds of social arrangements suited to sustained economic growth" (Rosenberg and Birdzell 1986 , p. 60), further study of this period seems likely to improve our understanding of how "good institutions" arise. In highlighting the importance of better understanding this era of economic history, it is my hope that the The Great Transition will encourage further research on this period, which seems both abnormally important and understudied.

\section{REFERENCES}

-Acemoglu, Daron. 2010. "When Does Labor Scarcity Encourage Innovation?" Journal of Political Economy 118 (6): 1037-78.

-Acemoglu, Daron, and Alexander Wolitzky. 2011. "The Economics of Labor Coercion." Econometrica 79 (2): $555-600$.

-Acemoglu, Daron, Simon Johnson, and James Robinson. 2005. "The Rise of Europe: Atlantic Trade, Institutional Change, and Economic Growth." American Economic Review 95 (3): 546-79.

- Bai, Jushan, and Pierre Perron. 2003. "Computation and Analysis of Multiple Structural Change Models." Journal of Applied Econometrics 18 (1): 1-22.

Berman, Harold J. 1983. Law and Revolution: The Formation of the Western Legal Tradition. Cambridge and London: Harvard University Press.

- Blaydes, Lisa, and Eric Chaney. 2013. "The Feudal Revolution and Europe's Rise: Political Divergence of the Christian West and the Muslim World before
1500 CE.” American Political Science Review 107 (1): 16-34.

- Blum, Jerome. 1957. "The Rise of Serfdom in Eastern Europe." American Historical Review 62 (4): 807-36.

Brenner, Robert. 1985. "Agrarian Class Structure and Economic Development in Pre-industrial Europe." In The Brenner Debate: Agrarian Class Structure and Economic Development in Pre-industrial Europe, edited by T. H. Aston and C. H. E. Philpin, 10-63. Cambridge and New York: Cambridge University Press.

- Buringh, Eltjo, and Jan Luiten van Zanden. 2009. "Charting the 'Rise of the West': Manuscripts and Printed Books in Europe, a Long-Term Perspective from the Sixth through Eighteenth Centuries." Journal of Economic History 69 (2): 409-45.

Campbell, Bruce M. S. 2016. The Great Transition: Climate, Disease and Society in the Late-Medieval World. Cambridge and New York: Cambridge University Press.

-Cantoni, Davide, and Noam Yuchtman. 2014. "Medieval Universities, Legal Institutions, and the Commercial Revolution." Quarterly Journal of Economics 129 (2): 823-87.

Chaney, Eric. 2012. "Separation of Powers and the Medieval Roots of Institutional Divergence between Europe and the Islamic Middle East." In Institutions and Comparative Economic Development, edited by Masahiko Aoki, Timur Kuran, and Gerard Roland, 116-30. New York: St. Martin's Press, Palgrave Macmillan.

-Chaney, Eric. 2015. "Measuring the Military Decline of the Western Islamic World: Evidence from Barbary Ransoms." Explorations in Economic History 58: $107-24$.

Chaney, Eric. 2016. "Religion and the Rise and Fall of Islamic Science." Unpublished.

-Chaney, Eric, and Richard Hornbeck. 2016. "Economic Dynamics in the Malthusian Era: Evidence from the 1609 Spanish Expulsion of the Moriscos." Economic Journal 126 (594): 1404-40.

De Hinojosa, Eduardo. 1903. Estudios sobre la Historia del Derecho Español. Madrid: Imprenta del Asilo de Huerfanos del Sagrado Corazón de Jesús.

Dols, Michael W. 1977. The Black Death in the Middle East. Princeton and Oxford: Princeton University Press.

Epstein, S. R. 2000. Freedom and Growth: The Rise of States and Markets in Europe, 1300-1750. London and New York: Routledge.

Greif, Avner. 2006. Institutions and the Path to the Modern Economy: Lessons from Medieval Trade. Cambridge and New York: Cambridge University Press.

Herlihy, David. 1997. The Black Death and the Transformation of the West. Cambridge and London: Harvard University Press.

North, Douglass C., and Robert Paul Thomas. 1970. "An Economic Theory of the Growth of the Western World." Economic History Review 23 (1): 1-17.

Pamuk, Sevket. 2007. "The Black Death and the 
Origins of the 'Great Divergence' across Europe, 1300-1600.” European Review of Economic History 11 (3): 289-317.

Phillips, J. R. S. 1998. The Medieval Expansion of Europe. Oxford and New York: Oxford University Press.

Rosenberg, Nathan, and L. E. Birdzell, Jr. 1986. How the West Grew Rich: The Economic Transformation of the Industrial World. New York: Basic Books.

- Stasavage, David. 2016. "Representation and Consent: Why They Arose in Europe and Not Elsewhere." Annual Review of Political Science 19: 145-62.

Thompson, I. A. A. 1994. "Castile: Polity, Fiscality, and Fiscal Crisis.” In Fiscal Crises, Liberty, and Representative Government 1450-1789, edited by Philip T. Hoffman and Kathryn Norberg, 140-80. Stanford: Stanford University Press.

Tilly, Charles. 1985. "War Making and State Making as Organized Crime." In Bringing the State Back In, edited by Peter B. Evans, Dietrich Rueschemeyer, and Theda Skocpol, 169-91. Cambridge and New York: Cambridge University Press.

Trubek, David M. 1972. "Max Weber on Law and the Rise of Capitalism.” Wisconsin Law Review 720 (3): 720-53.

van Bavel, Bas J. P., and Jan Luiten van Zanden. 2004. "The Jump-Start of the Holland Economy during the Late-Medieval Crisis, c. 1350-c. 1500." Economic History Review 57 (3): 503-32.

-Voigtlander, Nico, and Hans-Joachim Voth. 2013a. "Gifts of Mars: Warfare and Europe's Early Rise to Riches." Journal of Economic Perspectives 27 (4): 165-86.

-Voigtlander, Nico, and Hans-Joachim Voth. 2013b. "How the West 'Invented' Fertility Restriction." American Economic Review 103 (6): 2227-64.

-Voigtlander, Nico, and Hans-Joachim Voth. 2013c. "The Three Horsemen of Riches: Plague, War, and Urbanization in Early Modern Europe." Review of Economic Studies 80 (2): 774-811. 